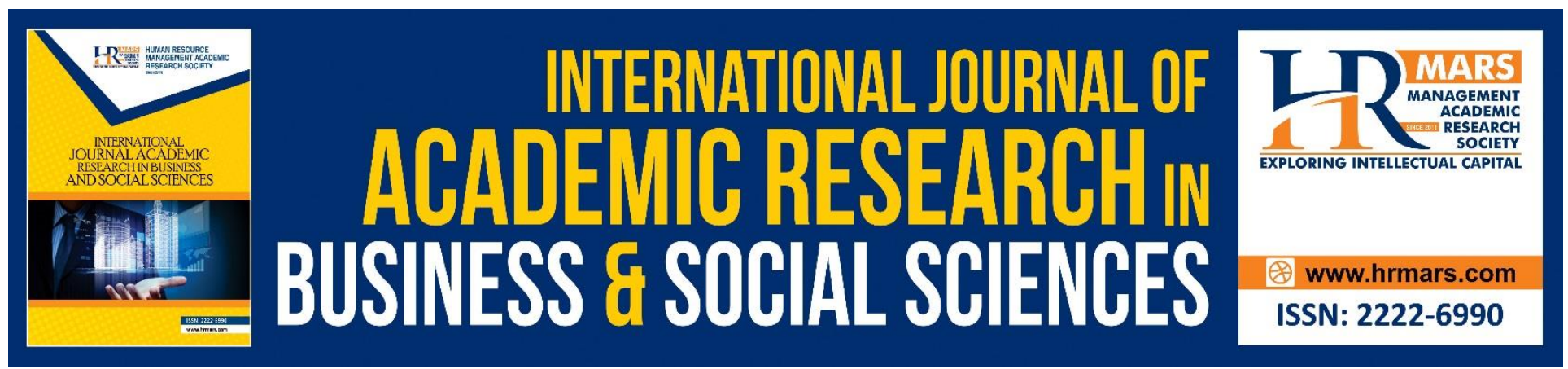

\title{
Relationship between Civil and Military in Disaster Response and Recovery
}

Nora Ibrahim, Haslinda Abdullah and Nur Hidayah Roslan

To Link this Article: http://dx.doi.org/10.6007/IJARBSS/v8-i6/4318

DOI: $\quad 10.6007 /$ IJARBSS/v8-i6/4318

Received: 24 May 2018, Revised: 19 June 2018, Accepted: 29 June 2018

Published Online: 08 July 2018

In-Text Citation: (Ibrahim, Abdullah, \& Roslan, 2018)

To Cite this Article: Ibrahim, N., Abdullah, H., \& Roslan, N. H. (2018). Relationship between Civil and Military in Disaster Response and Recovery. International Journal of Academic Research in Business and Social Sciences, $8(6), 1216-1223$.

\section{Copyright: (C) 2018 The Author(s)}

Published by Human Resource Management Academic Research Society (www.hrmars.com)

This article is published under the Creative Commons Attribution (CC BY 4.0) license. Anyone may reproduce, distribute, translate and create derivative works of this article (for both commercial and non-commercial purposes), subject to full attribution to the original publication and authors. The full terms of this license may be seen

at: http://creativecommons.org/licences/by/4.0/legalcode

Vol. 8, No. 6, June 2018, Pg. 1216 - 1223

http://hrmars.com/index.php/pages/detail/IJARBSS

JOURNAL HOMEPAGE

Full Terms \& Conditions of access and use can be found at http://hrmars.com/index.php/pages/detail/publication-ethics 


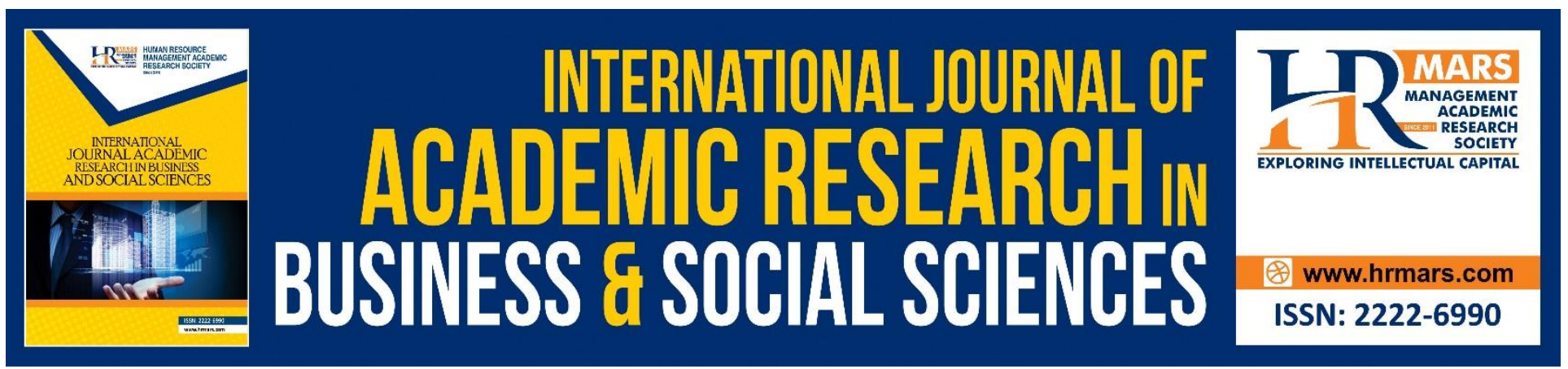

\title{
Relationship between Civil and Military in Disaster Response and Recovery
}

\author{
Nora Ibrahim, Haslinda Abdullah and Nur Hidayah Roslan \\ Faculty of Defence Studies and Management, National Defence University of Malaysia, \\ Sungai Besi Camp, 57000 Kuala Lumpur, Malaysia
}

\begin{abstract}
In recent years, military and civil agencies play an important role in disaster response and recovery. These include an increase in the scale and incident of natural disasters, a concurrent trend towards militarization of humanitarian response in conflict situations and increased interest in disaster response on the part of military. Hence, the Malaysian Armed Forces (MAF) and civil agencies play an effective role to ensure the effectiveness of managing the disaster response in that area. The objective of this study is to know the problems faced by the Malaysian Armed Forces and Civil Agencies in Sarawak. This study is to examine the civil-military cooperation between the Malaysian Armed Forces and civil agencies during the disaster, to examine the civil-military coordination in disaster management, and to examine the civil-military activities between armed forces and civil agencies and the activities carried out by the army and civil agencies and also the challenges faced during the response and recovery in disaster management. This study is based on qualitative research method through interviews and focus group discussion involving the military infantry unit at 11 Royal Malay Regiment, 13 Royal Malay Regiment, 3 Royal Ranger Regiment, and 10 Royal Ranger Regiment in Sarawak. There are also problems such as disagreement between the military and civil agency that weakened their professional relationship. It is important for the military and civil agency to have a good relationship in order to work together in managing the disaster.

Keywords: Civil-military Coordination, Civil-military Cooperation, and Civil-military Activities and Disaster Response and Recovery
\end{abstract}

\section{Introduction}

A disaster is an event that causes disruption to the activities of public and state affairs, involving loss of life, property damage, economic losses and environmental damage that goes beyond the ability of communities to cope and require extensive resource mobilization action. Agencies and the rescue teams at the federal level or state need to be ready for a rescue operation, transfer and distribution of the needs for the flood victims. The Malaysian Armed Forces (MAF), Royal Malaysian Police, Malaysian Fire and Rescue Department, Civil Defense Department, Social Welfare Department and several other agencies across the country are put on standby to provide assistance. Government assets that can be mobilized for flood operations across the country are placed according to the zone. 
INTERNATIONAL JOURNAL OF ACADEMIC RESEARCH IN BUSINESS AND SOCIAL SCIENCES Vol. 8, No. 6, June 2018, E-ISSN: 2222-6990 @ 2018 HRMARS

Some of the reasons for military personnel Increased interest in disaster response are related to public perception, staff morale, relevant training opportunities, and humanitarian operations as a means for armed forces to diversify their role and expertise. With the increased engagement of military personnel in humanitarian response to both conflict and natural disasters, interaction on the ground between humanitarian and military personnel has increased and has cast the spotlight on issues related to civil-military cooperation, coordination, and the effectiveness of militarized emergency assistance in general. The MAF in particular played an important role in the response to the floods in Sarawak. In addition, the research shows the importance of good relations such as cooperation, coordination and activity between the MAF and Civil Agencies during disaster response and recovery.

The MAF have sent troops of 3rd Brigade and mobilized On Dec 17, 2014, when the water level is getting high and require the evacuation operation. Brigade members played a key role in the rescue efforts by using assets such as assault boats and helicopters. In addition, seven trucks and three tons of capacity were used to transport food supplies and other necessities for the evacuees at the relief centers. Military assets from other camps across the country were deployed to Sarawak to help the mission. Statistics from the National Security Council (NSC) showed 17 boats, 18 trucks, four fourwheel drive vehicles, four helicopters and two ambulances were used by the MAF in their mission.

These extraordinary circumstances cause a working transfer requires the following number of victims as well as other factors which cannot be avoided including the case of refusal to move even after being persuaded and instructed to move that caused many to be stranded due to water rising too fast. The sudden increase in the number of victims exceeded initial expectations and discomfort that caused some congestion in the evacuation centers. The MAF and other agencies are also experiencing challenges in terms of logistics to deliver supplies due to adverse weather conditions and the flooded road. However, it did not dampen the spirit of the agencies involved and rescuers and now the situation has become more stable and better.

\section{Literature Review \\ Civil-Military Relations}

The terms civil-military coordination, civil-military cooperation and civil-military relations are often conflated in the literature. This is 'the essential dialogue and interaction between civilian and military personnel in humanitarian emergencies that is necessary to protect and promote humanitarian principles, avoid competition, minimize inconsistency, and when appropriate, pursue common goals. It provides for a spectrum of interaction between military and humanitarian personnel, ranging from co-existence to cooperation. 
INTERNATIONAL JOURNAL OF ACADEMIC RESEARCH IN BUSINESS AND SOCIAL SCIENCES Vol. 8, No. 6, June 2018, E-ISSN: 2222-6990 @ 2018 HRMARS

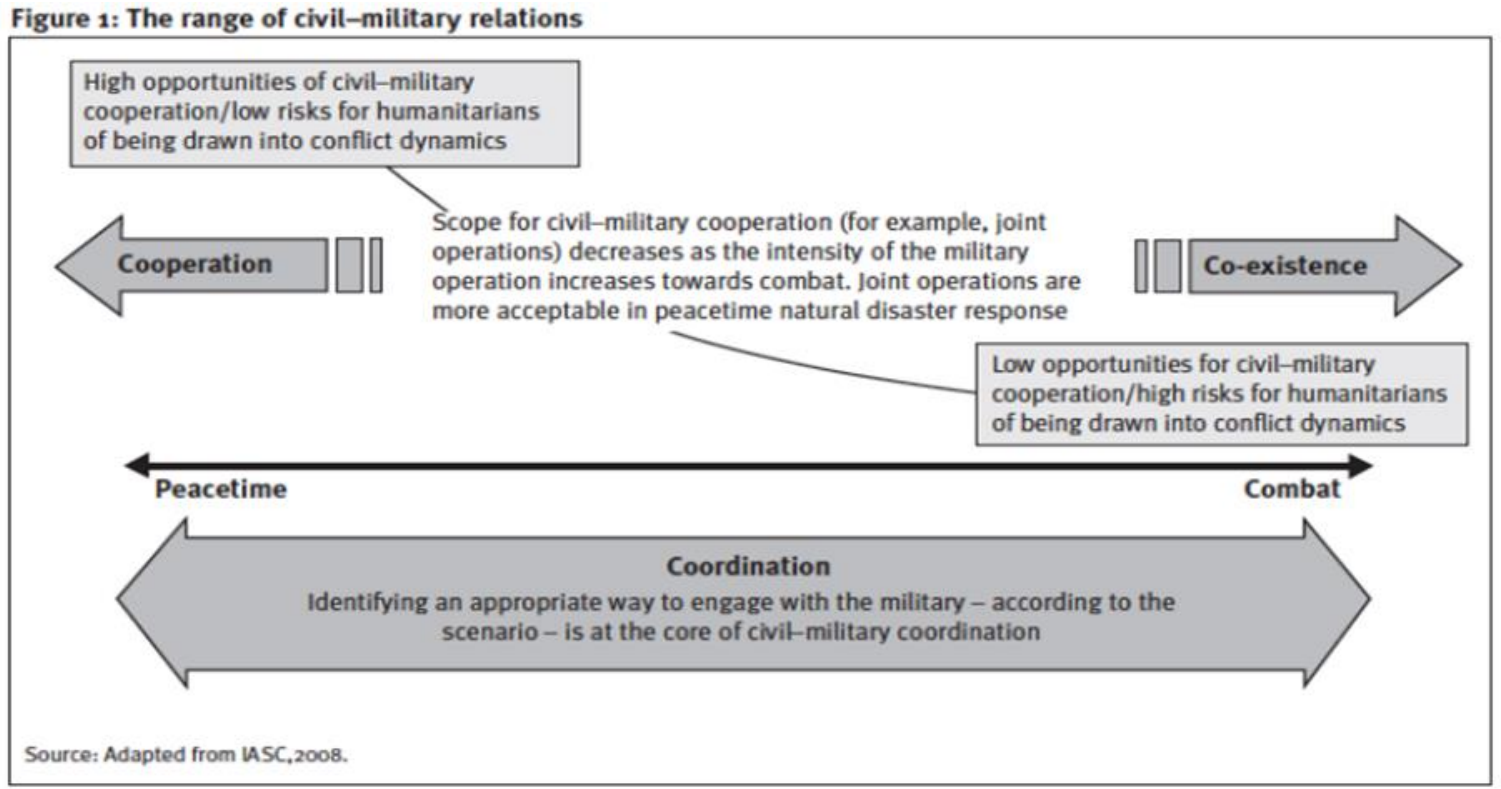

Figure 1: The Range of Civil-military Relations (Source: Victoria Metcalfe, Simone Haysom and Stuart Gordon, 2012)

\section{Civil-Military Coordination}

Civil-military coordination refers specifically to the interaction between humanitarian organizations and military personnel for humanitarian purposes. Whereas the broader term civil-military relations generally refer to the interaction between the military and a wider range of civilian personnel, including civil society, government authorities, rule of law, security sector reform, human rights and development personnel, and can be undertaken for a range of objectives. Their roles and responsibilities are covered in national disaster plans and in disaster-related legislation. These units regularly train and exercise with the civilian authorities (Lipner \& Henley, 2010). There is commitment at the highest level to regional disaster response as the head of government in most states is also the head of the national emergency management system. Civilian and 'disciplined forces' are forced to work together due to scarce resources - both in terms of civilian capacity and assets and the small scale of disciplined forces at both the national and regional level. As in all regions, effective civilmilitary coordination faces certain challenges and requires preparation of structures and procedures to ensure efficient outcomes. In order to build these institutions, an understanding is needed of the key personnel and their role to determine who is best equipped to lead the process of civil-military coordination (Rahman, 2012). The disaster management community and their partners need to determine, firstly, how best to prepare for complex disasters with the military in a supporting role and secondly, when it is efficient and effective to use foreign military assets. Stakeholders should also consider what kind of resources needed to support coordination, how time frames for preparedness and response activities should be determined, and what type of coordination \& cooperation arrangements are necessary (Martinez, 2015).

\section{Civil-Military Cooperation}

Civil-military cooperation is a military term, for which there are varying interpretations, but essentially it refers to the engagement of military personnel with civilians for military purposes. NATO defines Civil-military cooperation as the coordination and cooperation, in support of the mission, 
INTERNATIONAL JOURNAL OF ACADEMIC RESEARCH IN BUSINESS AND SOCIAL SCIENCES Vol. 8, No. 6, June 2018, E-ISSN: 2222-6990 @ 2018 HRMARS

between the NATO Commander and civil personnel, including national population and local authorities, as well as international, national and non-governmental organizations and agencies. Doctrinally, civil-military cooperation provides the military function through which commander's link to civilian agencies active in a theatre of operations (Marret, 2009). Although it is the responsibility of national governments to protect and assist those living in their countries when disasters strike, governments themselves are often weakened by disaster and lack the capacity to respond adequately. In some cases, this leads international players to substitute for governments, which can have the paradoxical effect of actually weakening national capacity. The international humanitarian system is already stretched to respond to present disasters; it will be even more stretched in the future. The humanitarian system that has been developed in the past five or six decades is made up of a multitude of personnel-UN agencies, government aid departments, the Red Cross Red Crescent movement, international and national non-governmental organizations, local civil society groups, military forces, and an increasing number of non-traditional participants such as business and militias. It is in this context of increasing numbers of disasters, growing pressure for responses and a complex world of humanitarian action that we turn to the question of the participation of military forces in disaster response and their relationship with civilian organization. Although the focus of the discussion is the military have very specific skills that are crucial to providing security for humanitarian operations. (Victoria, Simone and Stuart, 2012)

\section{Civil-Military Activities}

Military activities are associated with an operation that ensure that military commanders comprehend, make use of and mitigate any negative impact of the civil environment on military operations and plans. The activities of a commander that establish, maintain, influence, or exploit relations between military forces, governmental and nongovernmental civilian organizations and authorities, and the civilian population in a friendly, neutral, or hostile operational area in order to facilitate military operations, to consolidate and achieve operational objectives. Civil-military operations may include performance by military forces of activities and functions normally the responsibility of the local, regional, or national government. These activities may occur prior to, during, or subsequent to other military actions. They may also occur, if directed, in the absence of other military operations. Civil-military operations may be performed by designated civil affairs, by other military forces, or by a combination of civil affairs and other forces (Australian Defence Force, 2009).

\section{Methodology}

For the purpose of this research, Phenomenological method of qualitative research methods were use during interviews with few respective officers and other ranks to the military infantry unit at 11 Royal Malay Regiment, 13 Royal Malay Regiment, 3 Royal Ranger Regiment and 10 Royal Ranger Regiment in Sarawak. Qualitative study was also applied in order to get more detailed explanation on the issues. Structured interviews were also conducted with few officers who hold appointment in dealing with the disaster. The interviews were conducted to get a better comment, response, feedback and understanding of the overall situation in order to fulfill the requirements of this study. The structured interview questions were also designed to get their ideas and identify their expectations on how to achieve disaster response and recovery. 
INTERNATIONAL JOURNAL OF ACADEMIC RESEARCH IN BUSINESS AND SOCIAL SCIENCES Vol. 8, No. 6, June 2018, E-ISSN: 2222-6990 @ 2018 HRMARS

As for this research, in initial stage, in order to gain access, the researcher submitted a letter of requesting an access to conduct a research in the depot. Next, in gaining the respondents' consent, the respective respondents and participants were given an explanation on the objectives and purposes of the research. This action also was taken to get respondents' confidence and willingness to participate on voluntary basis. In order to assure the participants anonymity and confidentially of data, generalization of findings will be made. This is also to protect the respondents from any risk and harm. While conducting this study, the researcher had assumed the respondents' honesty and nonbiasness. Throughout this study, in order to ensure reliability, the credibility of the research, the researcher ensure all the data and information gathered through interviews with respondents were concluded without affecting the originality of the narratives.

\section{Findings}

\section{Civil-Military Coordination}

This study found that there is an interaction between the military and the civilian during disaster response and recovery in Sarawak. Military and other civil agencies took the responsibility together in managing the disaster response and recovery. Then, there are goals and objectives between military and civilian during the response and recovery phases of disasters. When managing disaster response and recovery, both military and the civil agencies have a goal and objective to manage the disaster at every stage of disaster management. The goal and objective for both military and civil agencies was the same, to save human's life and belongings during the disaster. Furthermore, the training about disaster was conducted by military and civil agencies. Both military and civil agencies are trained for the purpose of the issues. In addition, all the issues that arise from the military and the civilian can be overcome with proper manner in disaster management. The military and civil agencies always overcome their problem without any resistance. The findings of the civil-military coordination are similar as the past research conducted. It is important for the military and civil agency to have a good relationship in order to work together in managing the disaster.

\section{Civil-military Cooperation}

This study found that there is civil-military cooperation, which the core purpose is to obtain support and potential assets from the indigenous population, coordination and joint-planning with civilian agencies, and the provision of expertise, information, security, infrastructure and building capacity to the local population in support of the military mission. As a consequence, the distribution of civilmilitary cooperation effort tends to follow military priorities, and do not offer unconditional support to the humanitarian response. In addition, army troops require information from the public agency for disaster aid operations and determine the safety during disaster operations. In addition, military cooperate with civilian in providing temporary infrastructure for disaster response operations. Joint operations are carried out by the military and the civilian. Army troops were deployed as complementary in assisting the civilian in disaster response operations. Thus, there is a clear doctrine for the implementation of the cooperation between both civil and military in disaster response operations.

\section{Civil-military Activities}

This study found that there is a civil-military activity during the disaster such as search and rescue operations. Both civil and military were involved hand in hand in search and rescue operation to save victims during the disaster. Then, in terms of providing assistance to the victims and providing 
INTERNATIONAL JOURNAL OF ACADEMIC RESEARCH IN BUSINESS AND SOCIAL SCIENCES

Vol. 8, No. 6, June 2018, E-ISSN: 2222-6990 @ 2018 HRMARS

support assets such as boats for channeling aid. Both civil and military cooperated to provide shelter and temporary shelter to the victims and also worked together to renovate the buildings as temporary camp for the flood victims and provided health services, as well as cooperated to give a counseling to the victims.

\section{Conclusion}

Close coordination and cooperation between civilian and military communities is essential for numerous reasons. First, it speeds response and recovery by utilizing the best and the most appropriate assets where they will do the best. This allows relief personnel to reach devastated, remote locations with assets like helicopters tailored to the task, while other resources are used in more accessible areas. Coordination can also prevent duplication of efforts and the waste of lifesaving time and money. Finally, it promotes the timely flow of information from the host nation down to assisting state units and agencies and ultimately, to the people in the different communities. All of these components add up to one outcome, which is lives are saved. That is why, as we move into an uncertain future of stronger and more frequent disasters, civil-military coordination and civilmilitary cooperation prior to a disaster have become more critical. Saving lives before, during, and after a disaster could become a reality.

Robust civil-military coordination and civil-military cooperation efforts are required to manage the relationship between the military and humanitarian agencies, to facilitate an understanding of what their respective comparative advantages may be, where these may be complementary, and when it is necessary for tactical and conceptual reasons that the two strategies are, and are seen as being separated. All humanitarian action, including civil-military coordination for humanitarian purposes in complex emergencies, must be in accordance with the overriding core principles of humanity, neutrality and impartiality. These cardinal humanitarian principles as well as other important principles and concepts must be respected when planning or undertaking civil-military relation in disaster response and recovery.

\section{Acknowledgment}

This research works was funded by research grant, NRGS/2013/UPNM/PK/P2, National Defense University of Malaysia.

\section{Corresponding Author}

Nora Binti Ibrahim; Faculty of Defence Studies and Management, National Defence University of Malaysia, Sungai Besi Camp, 57000 Kuala Lumpur, Malaysia; Email: nora_am91@yahoo.com

\section{Reference}

Australian Defence Force (2009) Operations Series ADDP 3.11 Civil Military Operations.

Bamdad, N. (1999) The role of community knowledge in disaster management: The Bam Earthquake Lesson in Iran

Bennett, N. (2011) 'Civil-Military Principles in the Pakistan Flood Response', Humanitarian Exchange, no. 49.

Bruderlein, C. and J. Leaning (1999) 'New Challenges for Humanitarian Protection', British Medical Journal, 319, 14 August. 
INTERNATIONAL JOURNAL OF ACADEMIC RESEARCH IN BUSINESS AND SOCIAL SCIENCES

Vol. 8, No. 6, June 2018, E-ISSN: 2222-6990 @ 2018 HRMARS

Clausewitz, von Karl (1976). On War (translated and edited by Michael Howard and Peter Paret). Princeton, New Jersey: Princeton University Press, 1976.

Eriksson, P. (2000). 'Civil-Military Co-ordination in Peace Support Operations - An Impossible Necessity?', www. jha.ac/articles/a061.htm, accessed on 16 September 2000.

F. Wendy and L. Sean (2013) Civil-military coordination and the protection of civilians in South Sudan: South Sudan Case Study, NRC and HPG.

Feaver, P. (2002). Armed Servants: Agency, Oversight and Civil Military Relations. Cambridge, Massachusetts: Harvard University Press, 2002

Harmer, A. and Mosel, I. (2012) Strengthening Principled Humanitarian Response Capacities: South Sudan Case Study, NRC and HPG.

Janowitz, M. (1960). The Professional Soldier: A Social and Political Portrait. Glencoe, Illinois: Free Press.

L.Perez, C. (2007) Emergency Communications for Disaster Management In this issue

Lie, J. H. S and Carvalho, D. (2009) 'Protecting Civilians and Protecting Ideas: Institutional Challenges to the Protection of Civilians', Security in Practice, 4, 2009, NUPI Working Paper 760

Macfarlane, N. (2000) Politics and Humanitarian Action. Providence, RI: Watson Institute.

Martin, J. R. (2000) Disaster Response and Recovery. Earthquake Hazard and Emergency Management

Meliti, D. (1999). Disasters by Design: A Reassessment of Natural Hazards in the United States. Joseph Henry Press. Chapters 7, 8, and 9, pp. 209-289.

NGO-Military Contact Group (NMCG) (2011) Conference Proceedings: Civil-Military Relations in Natural Disasters: New Developments from the Field, 12 October.

Rahman, J. A., Vaughan, C., Martin, S. (2012) "Stakeholder service delivery expectations of military facilities management", Built Environment Project and Asset Management, Vol. 2 Issue: 2, pp.146-166, https://doi.org/10.1108/20441241211280891

Reindorp, N. and Wiles, P. (2001). 'Humanitarian Coordination: Lessons from Recent Field Experience', A study commissioned by the Office for the Coordination of Humanitarian Affairs (OCHA), Overseas Development Institute (ODI), London.

Studer, M. (2001) 'The ICRC and Civil-Military Relations in Armed Conflict', International Review of the Red Cross, vol. 83, no, 842, June.

Slim, H. (2011) NGO-Military Contact Group: Keynote Address, Conference on Civil-Military Relations in Natural Disasters: New Developments from the Field, 12 October.

Victoria, M., Simone, H. and Stuart, G. (2012) Trends and challenges in humanitarian civil-military coordination: A review of the literature. 